\title{
CDC25B wt Allele
}

National Cancer Institute

\section{Source}

National Cancer Institute. CDC25B wt Allele. NCI Thesaurus. Code C104837.

Human CDC25B wild-type allele is located in the vicinity of 20p13 and is approximately 19

$\mathrm{kb}$ in length. This allele, which encodes M-phase inducer phosphatase 2 protein, is involved in control of progression through the cell cycle. 